\title{
The safety and quality of sous vide food
}

\author{
Natasa Kilibarda , Ivana Brdar', Branislav Baltic ${ }^{2}$, Vladan Markovic ${ }^{1}$, Hava Mahmutovic ${ }^{3}$, \\ Nedjeljko Karabasil ${ }^{4}$, Svetlana Stanisic ${ }^{1}$
}

A b s $t r$ a $c$ t: The demands of contemporary health conscious consumers are increasingly focused on minimally processed, convenient and affordable food that retains its natural sensory qualities along with nutritional value. In order to fully respond to these expectations, the use of sous vide processing technology, which refers to cooking vacuum-sealed food in heat-stable plastic pouches under precisely monitored conditions, has been widely adopted. Due to the low temperatures of sous vide processing, most research on this processing method is associated with biological hazards such as Listeria monocytogenes, Bacillus cereus and Clostridium botulinum. Not only has sous vide long been accepted by the food industry, in recent years, it has also been applied in households and in restaurants which are searching for innovative ways to attract more health conscious consumers. In this review, the authors present basic techniques, benefits and disadvantages of sous vide cooking and consider the great efforts the modern food industry is undertaking to extend shelf-life, ensure microbiological safety and maintain nutritional and organoleptic quality of sous vide food products.

Keywords: sous vide, food, microbiological safety, nutritional quality, gastronomy.

\section{Introduction}

Different food choices in human history have resulted from complex interactions of nutritional requirements, ecology, historical events and human logic or lack thereof (Anderson, 2005). Greenland Inuits consume more than $400 \mathrm{~g}$ of fish per day, vegans avoid animal-based food products while Maasai of Kenya and Tanzania mostly rely on meat and milk, but all of them have adequate nutrient consumption (Oniang'o, 2016; Jacob, 2016; Odusanya and Atanda, 2018). While our human ancestors ate to survive and maintain body temperature, for some of their modern descendants, food requirements are far beyond the primary instinct for self-sustainment. For the contemporary human, gustatory, olfactory and visual attributes of food are undoubtedly important drivers of food choice and intake. Hence, the tendency for sensation-seeking and the desire to taste and explore the unknown and unfamiliar is deeply rooted in the long story of human evolution. In addition to this, food serves as a communication tool for defining one's individuality and is an indicator of religion, ethnicity and culture, lifestyle affiliation, class and other social groupings, and therefore, the maintenance of food habits can serve as a cohesive force in an unfamiliar environment (Kalenjuk et al., 2015; Henderikx, 2017). In the modern world of hedonism, food shows off wealth, personal power and authority (Baltic et al., 2010). Moreover, consumption of special-status foods is utilised by elite groups and by people aspiring to higher social ranking (Baltic et al., 2010). When it comes to health aspects of dietary habits, a vast number of literature sources over the last few decades have been focused on exploring the adverse effects of recent shifts towards indulgent, high-fat and high-sugar diets (Caplan, 2013). Nowadays, the limited time available for cooking at home and lack of cooking skills are the main barriers to the adoption of healthy dietary choices. Therefore, modern consumers often search for pre-prepared food commodities that are nutritionally valuable, safe for use, free of additives and preservatives, affordable and feature similar sensory qualities to those of home-prepared food (García-Linares et al., 2004; Kilibarda, 2010; Kalenjuk et al., 2015). Finally, apart from food's contribution to human existence, longevity and physical sensations, food is intimately bound with one's emotional state. The memories of personal events evoked by eating experience can provide strong and complex relationships to early

${ }^{1}$ Singidunum University, 32 Danijelova st., 11010 Belgrade, Republic of Serbia;

2Institute of Meat Hygiene and Technology, 13 Kacanskog st, 11000 Belgrade, Republic of Serbia;

3University of Tuzla, Faculty of Technology, 8 Univrzitetska st., 75000 Tuzla, Bosnia and Herzegovina;

${ }^{4}$ University of Belgrade, Faculty of Veterinary Medicine, Bulevar oslobodjenja 18, 11000 Belgrade, Republic of Serbia.

Corresponding author: Natasa Kilibarda, nkilibarda@singidunum.ac.rs 
childhood experiences, or certain occasions in later life. From a psychological point of view, consumer memory is a significant predictor of a food product's success on the market. In this context, consumer memory encompasses the emotions experienced during eating and the after-effects of the meal all weighted and integrated by the person in an individual way. This emotional content from past eating experiences forms the basis for every consumer's future expectations, as well as for their perception and appreciation of food. In spite of their importance, emotional responses to food triggered by events such as memories of a grandmother's cuisine, dinner with friends or fine dining on exotic trips have been often neglected in food-related consumer research (Drpic and Vukman, 2014; Köster and Mojet, 2015).

The aim of this paper is to consider the potential benefits and risks associated with consumption of sous vide food. Sous vide is a modern food preparation technique that addresses the expectations of demanding consumers for minimally processed, safe, nutritionally valuable food which has visual appeal, smell, taste and texture comparable with those of fresh food (Schellekens, 1996).

\section{Brief history}

The French term sous vide means "under vacuum". In contrast to conventional food, sous vide food is vacuum-sealed in heat-stable, food-grade plastic pouches, and subjected to precisely monitored temperatures over a pre-determined period of time (Schellekens, 1996; Baldwin, 2012). In recent decades, this sophisticated technique has been applied to plant foods, such as green bean pods, red cabbage, carrots and other root vegetables (Iborra-Bernad et al., 2013; Iborra-Bernad et al., 2014a; Trejo Araya et al., 2009), as well as meat (Vaudagna et al., 2008; Sánchez del Pulgar et al., 2012; Roldán et al., 2015; Botinestean et al., 2016) and fish (Gonzalez-Fandos et al., 2004; Picouet et al., 2011; García-Linares et al., 2014; Espinosa et al., 2015; Dimitrijevic et al. 2015). While sous vide cooking has been a part of the food industry for years, primarily because of its price and efficiency, in recent times, it has become more affordable for application in households and restaurants.

The modern era of sous vide cooking began in the 1970s when French biochemist and microbiologist Bruno Goussault observed that by using low temperatures (about $60^{\circ} \mathrm{C}$ ) to cook vacuum packed beef, tender cuts with a juicy texture could be prepared, and according to him, that was exactly what consumers expected. The low-temperature food processing resulted in a final product that had better sensory attributes compared to conventionally prepared food. In contrast to Goussault, who has been researching the application of sous vide techniques in the food industry, European chefs have questioned the possibility of using sous vide techniques in restaurant kitchens (Keller, 2008). These directions of research (scientific and culinary) have resulted in two different applications of the sous vide cooking: one is in the food industry and serves for production of thousands of ready-prepared frozen meals in factory conditions, which are intended for home use after reheating; the other approach employs sous vide in restaurants and hotels for preparation of meals intended for uninterrupted in-house usage (Nyati, 2000). Nowadays, the expansion of the sous vide food market is driven by emerging circumstances - fewer family meals are prepared at home because employed parents face everyday challenges, struggling to integrate inflexible working hours and family lives (Devine et al., 2006), while at the same time, the numbers of single and senior households in developing countries are growing, with people who are determined and have time to improve their dietary habits by adopting new cooking techniques. Apart from home consumers, the potential users of sous vide cooking techniques include commercial catering, food retailers, hotels and restaurants, airlines, trains, cruise ships, defence forces, hospital kitchens, the health-food market and schools (Nyati, 2000).

\section{Sous vide equipment}

The preparation of sous vide food necessitates higher training and monitoring costs as well as specialised equipment including: a) water bath or steam oven, b) vacuum packaging machine, c) pouches/vacuum bags, and d) needle thermometer. The vacuum packaging machine eliminates the air from the food packaging and draws different degrees of vacuum depending on the type of foodstuff, then seals the package so it remains impermeable to air. As regards vacuum degree, high pressure is not recommended for sous vide processing of fish fillets, since the texture of fish is very gentle, and strong pressure would damage the tissue. This type of food cannot be completely vacuumed, and the residual pressure inside the package typically amounts to 100-120 mbar. On the other hand, sous vide processing of root vegetables utilises high pressure in order to achieve the most efficient thermal treatment. For firm and physically resistant 
food ingredients, the residual pressure inside the package can be as low as 10-15 mbar. Plastic polymers for sous vide vacuum bags must have certain features: they must be temperature- and pressure-resistant, must have low permeability to gases and moisture, and must have the chemical composition to provide limited migration of plastic residues to food (De Baerdemaeker and Nicola, 1995; Schellekens, 1996).

After sealing, the plastic pouches are completely immersed in a water bath or placed into a hot steam oven, in which the temperature is constantly monitored and adjusted (Carlin, 2014). The needle thermometer, which is used to monitor the temperature of cooking, should be regularly calibrated by an accredited laboratory.

\section{Processing of sous vide foods}

Sous vide cooking encompasses two types of products that differ in their production patterns - cook-hold or cook-serve and cook-chill or cook-freeze food (Stringer and Metris, 2018). Cook-hold or cook-serve sous vide techniques are intended for uninterrupted food processing in restaurants and households and include the following steps: food preparation, vacuum packaging, heating or pasteurising, finishing and serving. On the other hand, cook-chill or cook-freeze sous vide techniques include food preparation, vacuum packaging, heating or pasteurising, and finally refrigerating or rapid freezing in industrial conditions. This ready-to-take type of sous vide product is intended for use at home after reheating or re-thermalising and serving (Baldwin, 2012).

In contrast to conventional cooking, the temperatures of sous vide processing are typically in the range from 65 to $95^{\circ} \mathrm{C}$, with temperatures commonly exceeding $70^{\circ} \mathrm{C}$, but not $100^{\circ} \mathrm{C}$ (Schellekens, 1996; Carlin, 2014). There are four general time-temperature regimes for sous vide processing: i) $90^{\circ} \mathrm{C}$ for 10 minutes; ii) $70^{\circ} \mathrm{C}$ for 2 minutes (this process results in a large log reduction of vegetative cells, without affecting spores, and the products obtained by application of this temperature-time regime are usually frozen after processing); iii) minimum heating process with optional pasteurisation; and iv) light processing, which refers to neither cooking nor pasteurisation (Steward and Onyeaka, 2015).

The lowest sous vide temperatures are applied to fish, seafood and meat processing $\left(50-75^{\circ} \mathrm{C}\right.$, with an average temperature of $55^{\circ} \mathrm{C}$ ) and maintained for several hours or even days, while the highest temperatures of $90-100^{\circ} \mathrm{C}$ (with an average temperature of $85^{\circ} \mathrm{C}$ ) are applied to vegetable processing, which typically takes only a few minutes. For red meat which is cooked for less than 4 hours, the average temperature is $56^{\circ} \mathrm{C}$, while for red meat which is cooked for 4 hours or more, the average temperature is up to $60^{\circ} \mathrm{C}$. The average sous vide temperature for poultry is $63.5^{\circ} \mathrm{C}$, egg products are prepared at $64.5^{\circ} \mathrm{C}$ and dairy products at $82^{\circ} \mathrm{C}$ (Stringer and Metris, 2018).

The shelf-life of sous vide products depends on both the temperature-time treatment and the storage temperature, and typically ranges from 6 to 42 days (Schellekens, 1996; García-Linares et al., 2004).

\section{The advantages of sous vide food}

The current evidence from relevant literature suggests that sous vide food has a number of advantages, and the most important benefits of sous vide food are associated with, but not limited to: prevention of aerobic bacterial growth, low-risk of contamination after the packaging step, efficient heat transfer from oven or water to the food inside the package, minimal loss of volatile flavour compounds and moisture during thermal processing, superior sensory quality of product and inhibition of oxidation and related off-flavours (Carlin, 2014). Continuously monitored conditions contribute significantly to the success of sous vide techniques, to the extent that some authorities consider the name "precise cooking" more appropriate for this type of thermal processing than the current designation (Keller, 2008). Furthermore, following a specific processing regime results in food product of consistent, reliable and reproducible sensory qualities that strongly affects consumers' loyalty.

Plastic foil prevents the loss of aromatic volatile compounds and water during sous vide cooking, which enhances sensory attributes and contributes to juiciness and tenderness of meat. Additionally, the meat, compressed during the sous vide packaging, retains many of its desirable qualities, palatability, natural colour and the shape into which it has been formed, and this fresh appearance of meat is pleasing and acceptable to consumers (Roascio-Albistur and Gámbaro, 2018). Roldán et al. (2015) reported the formation of volatile compounds in the amino acid-involved reactions during sous vide processing of lamb meat. As suggested, the aromatic volatiles were associated with a specific savoury flavour, due to which fewer spices and less salt was required. 
In addition to this, mild sous vide thermal treatment has a superior capability to preserve nutritional value of food (Baldwin, 2012; Iborra-Bernad et al., 2013, 2014a; Kosewski et al., 2018) and to minimise the generation of chemical species known for their deleterious effects on human health, such as heterocyclic amines and polycyclic aromatic hydrocarbons. Mutagenic and carcinogenic polycyclic aromatic hydrocarbons and the main compound of concern in this group, benzopyrene, are formed during the incomplete combustion or pyrolysis of organic material and become concentrated in well-cooked meat during charcoal-broiling, grilling and traditional smoking (Kilibarda et al., 2009), but do not form during sous vide processing. Due to the fact that sous vide's plastic pouches prevent direct contact between food and oxygen, the oxidation of plant pigments, chlorophyll and carotenoids is limited and the colour of vegetable tissue is preserved (Rondanelli et al., 2017). Food colour is known to be one of the most desirable sensory attributes associated with freshness (Baltic et al., 2007). Iborra-Bernad et al. (2014a) found sous vide red cabbage had brighter colour, more intensive taste and aroma, and higher anthocyanin content than traditionally cooked cabbage.

\section{Physicochemical characteristics of sous vide foods}

Sous vide foods are commonly prepared without the additives widely used in traditional food production. The $\mathrm{pH}$ and water activity of sous vide foods are similar to those of the raw ingredients. In order to enhance the taste, salt is often added, but in concentrations that do not affect water activity, which is reported to be over 0.98 , and even more often over 0.99 in final sous vide product (Carlin, 2014).

Because of the elimination of air/oxygen during vacuum packaging, sous vide foods provide either strictly anaerobic conditions or contain a small amount of residual air/oxygen that should theoretically inhibit the growth of strictly anaerobic bacteria. However, this is not the case in practice - it has been shown that growth and reproduction of strict anaerobes is possible despite the presence of low levels of oxygen (Baldwin, 2012; Djordjevic et al., 2016; Stringer and Metris, 2018). Due to the fact that the physicochemical features of sous vide foods are suitable for the growth of a wide range of bacteria, which is further supported by low processing temperatures, much of the research dealing with sous vide processing has been focused on the microbiological safety of sous vide products.

\section{The safety of sous vide products}

The research dealing with sous vide food and related issues since the 1990s has mainly focused on exploring the effects of sous vide cooking on extending food sustainability. Apparently the research outcomes and contribution to knowledge in the field of food science have been substantial, since to date, no case of foodborne disease caused by sous vide food has been recorded in scientific literature (Peck et al., 2006).

The majority of sous vide processing includes long-term (in the bacteriological sense) treatment in the temperature danger zone between 4 and $60^{\circ} \mathrm{C}$. Such circumstances would normally allow pathogens to grow and reproduce to numbers that are sufficient to cause foodborne disease (Stringer and Metris, 2018). The safety of sous vide products mostly relies on: (i) temperature control during cooking, (ii) rapid cooling, and (iii) temperature control during storage (Schellekens, 1996; Gonzalez-Fandos et al., 2005).

As shown by a number of studies, the presence of pathogens in final sous vide products most likely results from those microorganisms being in raw ingredients and surviving during processing. The pathogens of concern in sous vide food can be divided into four categories. The first category is that of the vegetative bacteria that are unable to grow at refrigeration temperatures, such as Escherichia coli, Salmonella, Vibrio, Staphylococcus aureus and Campylobacter. These bacteria are predominantly inactivated by pasteurisation. The second category includes vegetative bacteria that can grow and reproduce at refrigeration temperatures such as Listeria monocytogenes, Yersinia and Aeromonas. Most of these bacteria are sensitive to pasteurisation temperatures, but some cells can survive mild heat treatment. The third category of concern is the psychrotrophic spore-forming pathogenic bacteria that are able to survive pasteurisation treatments and then grow and reproduce at low storage temperatures (Church and Parsons, 1993). These include non-proteolytic Clostridium botulinum, enterotoxigenic E. coli and spore-forming, psychrotrophic Bacillus cereus. Finally, the fourth category is the mesophilic spore forming bacteria that are able to survive pasteurisation treatments, but are unable to grow and reproduce at refrigeration temperatures, such as proteolytic Clostridium botulinum, mesophilic B. cereus and Clostridium perfringens (Stringer and Metris, 2018).

Vacuum packed sous vide food could provide favourable conditions for the growth and reproduction of anaerobic bacteria, ideal for one of the 
major biological hazards cited for sous vide processing, C. botulinum (Nyati, 2000). Clostridium botulinum type $\mathrm{E}$ is able to grow and produce toxin at $3^{\circ} \mathrm{C}$ (Briley, 1992; Jay, 1992; Gould, 1999; Kilibarda, 2010). Furthermore, any leakages in the seal and/ or packaging bags could result in contamination of sous vide product with other types of pathogens during production or storage (Nyati, 2000).

Cook-hold or cook-serve sous vide techniques are considered relatively safe due to the fact that the food is consumed immediately after preparation, usually with a delay of not longer than two hours, during which food is stored at temperatures above $54.4^{\circ} \mathrm{C}$ to prevent or slow down the reproduction of pathogenic bacteria (Baldwin, 2012; Carlin, 2014; Stringer and Metris, 2018). For these types of sous vide products, the pathogenic bacteria of concern are Salmonella and pathogenic E. coli because they are relatively heat resistant and a small number of vegetative bacteria can cause alimentary infection in immunocompromised people (Baldwin, 2012).

On the other hand, cook-chill or cook-freeze is more popular, involving food products that are consumed reheated after days or weeks of cold storage. In these foods, the pathogenic bacteria of concern are L. monocytogenes, B. cereus and C. botulinum (Baldwin, 2012, Carlin, 2014; Stringer and Metris, 2018). L. monocytogenes is generally considered to be the most heat-resistant vegetative pathogen, and in food with high water activity, it can grow anaerobically below $4^{\circ} \mathrm{C}$ (Dimitrijevic et al., 2008). For this reason, pasteurisation is a critical control point for the prevention of Listeria growth in cook-chill or cook-freeze sous vide food. The European Union guidelines recommend the minimum heat treatment for sous vide pasteurisation is equivalent to heating at $70^{\circ} \mathrm{C}$ for two minutes (ECFF, 2006; Stringer and Metris, 2018).

B. cereus and C. botulinum are considered important pathogens in heat-treated foods, because of their ability to produce spores and toxins. Therefore, the recommended shelf-life of sous vide foods is limited to 10 days (Peck et al., 2008), except if the storage temperature is below $2.5^{\circ} \mathrm{C}$, when shelf-life should not exceed 90 days (Baldwin, 2012). According to Baldwin (2012), shelf-life and storage temperature of sous vide foods are critical factors for preventing spores of non-proteolytic C. botulinum from outgrowing and producing neurotoxin. Although sous vide vacuum packs contain some residual oxygen, it might not be sufficient to inhibit the growth and reproduction of strictly anaerobic species such as Clostridium, which could grow inside the product (Kilibarda, 2010; Carlin, 2014).
It should be noted that consumption of sous vide food could be also associated with non-bacterial infection or intoxication risks from Norwalk virus, Rotavirus and hepatitis viruses, and parasites such as Trichinella, Taenia, Toxoplasma, Cryptosporidium and Giardia. It is very important to design guidelines for the safe production of unheated foods where the presence of such pathogens is a risk (Stringer and Metris, 2018). Proper design and implementation of a hazard analysis and critical control point (HACCP) system with its prerequisite programes (good manufacturing practice/good hygienic practice) is considered the best preventive measure for foodborne illnesses generally. The food safety criteria related to biological hazards for sous vide processing are mainly based on HACCP, which is recommended at all stages of sous vide production, storage and distribution for control of microbiological and other hazards. This includes trained personnel using specialised time-temperature recorders to monitor potential temperature abuse at all stages of production and storage (Roascio-Albistur and Gámbaro, 2018). Furthermore, the use of high-quality, HACCP-controlled ingredients is critical for assuring high-quality and safety of final products, as is the uniform heating of the food that is achieved by complete soaking in a water bath.

The optimal growth temperature of most pathogenic bacteria is between 30 and $50^{\circ} \mathrm{C}$, whereas inhibition of bacterial growth and reproduction starts at temperatures above $52.3^{\circ} \mathrm{C}$. Thus, the core temperature of sous vide food during processing should not be below $54.4^{\circ} \mathrm{C}$ and it should be maintained for 6 hours. When the prepared sous vide food is served immediately after thermal processing, no risk of pathogen growth exists. However, if sous vide product is frozen for later use, freezing must be conducted rapidly and immediately following the thermal procedure to prevent/limit risks, e.g. toxin production by $C$. perfrigens during the formation of spores. Furthermore, storing sous vide food in vacuumed pouches is appropriate for preventing recontamination, while toxin production by $C$. botulinum and $B$. cereus is prevented by proper storing at correct temperatures in a refrigerator or freezer (Baldwin, 2012; Stringer and Metris, 2018).

\section{The nutritional quality of sous vide food}

The fact that sous vide food is processed in low oxygen environments, under mild and precisely controlled temperatures is important for preserving the nutritional content of final product without ignoring consumers' sensorial experience and satisfaction 
(Iborra-Bernad et al., 2014b). In contrast to conventional cooking, the plastic pouches used in sous vide minimise the loss of minerals and can enhance their bioavailability (Ronadelli et al., 2017). Da Silva et al. (2017) confirmed these findings by exploring the bioavailability of calcium, cooper, iron, potassium and magnesium from bovine liver. In addition to this, sous vide food processing is superior than widespread steaming and boiling in terms of preventing the loss of vitamins, particularly those most vulnerable to high temperatures and the presence of oxygen, including thiamine (vitamin B1), riboflavin (vitamin B2) and ascorbic acid (vitamin C) (Petersen, 1993; Creed, 1995). Furthermore, the content of anthocyanins and polyphenols in sous vide vegetables remains comparable to that of fresh plants (Baardset et al., 2010; Iborra-Bernad et al., 2015; Renna et al., 2014), and a number of studies have confirmed that sous vide red onion, shallot, broccoli, tomato, green beans, artichokes, carrots, parsley root and cauliflower retain their antioxidative potential (Kosewskia et al., 2018; Guillén et al., 2017).

Adding small amounts of fat to food ingredients prior to vacuum sealing prevents adhesion of proteins to the pouch cooking surfaces and improves texture, juiciness and flavour of final product. The plastic barrier significantly limits diffusion of oxygen into the food and subsequent oxidation of lipids, which is important for preserving the quality and health benefits of essential polyunsaturated fatty acids in human nutrition (Pavlicevic et al., 2014). As confirmed by Schellekens (1996), the oxidation of unsaturated fatty acids was less pronounced in sous vide fish than in fish prepared at the higher temperatures during traditional cooking.

\section{Conclusions}

Sous vide food processing confers numerous advantages with regards to the quality of the final products, primarily the preservation of nutritional ingredients in foods, and the excellent sensory characteristics such as well-preserved colours, rich flavours, and intense tastes. Sous vide satisfies, to a significant extent, the demands of consumers who are searching for quality, nutritionally valuable food with sensory properties similar to those of raw food. As regards safety of sous vide food, special attention should be paid to choice of raw ingredients, continual control of processing (temperature/time regime), temperature control during storage and proper determination of shelf-life of the final product. While sous vide food products can be considered safe, this does not mean that foodborne illness outbreaks will never happen, particularly when having in mind the specific features of sous vide processing, i.e. mild heat treatment and avoidance of preservatives. Therefore, it is important to strictly adhere to the requirements of prerequisite programs (good manufacturing practice/good hygienic practice) and to safety criteria based on the HACCP approach. As a modern food preparation technique, sous vide provides opportunities for restaurants and food industries to expand their product base and, thus, achieve greater profits and become more competitive on the market. By applying well-designed marketing, sous vide processing should help food manufacturers gain consumers who are interested in healthy diets and new food experiences.

Disclosure Statement: No potential conflict of interest was reported by the authors.

\section{References}

Anderson, E. N. (2014). Everyone eats: understanding food and culture. NYU Press.

Baldwin, E. D. (2012). Sous vide cooking: A review. International Journal of Gastronomy and Food Science 1, 15-30

Baltic, Z. M., Andjelkovic, R., Stevanovic, J., Karabasil, N., Dimitrijevic, M. \& Kilibarda, N. (2007). Importance of the Sense of Smell in the Sensory Analysis of Food, Meat Technology, 48 (1-2), 131-137.

Baltic, Z. M., Nedic, D., Djuric, J., Dimitrijevic, M., Karabasil, N. \& Kilibarda, N. (2010). Food and everlasting concern about health. Veterinary Journal of Republika Srpska, 10 (1), 5-10.

Botinestean, C., Keenan, D. F., Kerry, J. P. \& Hamill, R. M. (2016). The effect of thermal treatments including sous vide, blast freezing and their combinations on beef tenderness of M. Semitendinosus steaks targeted at elderly consumers. LWT - Food Science and Technology, 74, 154-159.

Briley, M. E. (1992). Sous vide processed foods: are they safe for the elderly? Journal of Nutrition for the Elderly, 11 (3), 45-52.

Caplan, P. (2013). Food, health and identity. Routledge.

Carlin, F. (2014). Microbiology of Sous vide Products. In. Encyclopedia of Food Microbiology. Eds. C. A. Batt \& M. L. Tortorello, Elsevier, London, UK, pp. 621-626.

Church, I. J. \& Parsons, A. L. (1993). Review: sous vide cook-chill technology. International Journal of Food Science and Technology, 28, 563-574. 
Creed, P. G. (1995). The sensory and nutritional quality of 'sous vide' foods. Food Control, 6 (1), 45-52.

Da Silva, F. L. F., de Lima, J. P. S., Melo, L. S., da Silva, Y. S. M., Gouveia, S. T., Lopes, G. S. \& Matos W. O. (2017). Comparison between boiling and vacuum cooking (sous vide) in the bioaccessibility of minerals in bovine liver samples. Food Research International, 100 (1), 566-571.

De Baerdemaeker, J. \& Nicola B. M. (1995). Equipment considerations for sous vide cooking. Food Control, 6 (4), 229-236.

Devine, C. M., Jastran, M., Jabs, J., Wethington, E., Farell, T. J. \& Bisogni, C. A. (2006). “A lot of sacrifices:” Workfamily spillover and the food choice coping strategies of low-wage employed parents. Social Science \& Medicine, 63 (10), 2591-2603.

Dimitrijevic, M., Karabasil, N., Kilibarda, N., Teodorovic V. \& Baltic, M. Z. (2008). Control of Listeria monocytogenes in food production plants. Veterinarski Glasnik, 62 (5-6), 301-315.

Dimitrijevic, M., Boskovic, M., Baltic, M. Z., Karabasil, N., Teodorovic V., Vasilev, D., Katic, V., 2015. The importance and use of nanopacking in food industry. Veterinarski Glasnik, 69 (1-2), 130-154.

Drpic, K. \& Vukman, M. (2014). Gastronomija kao vazan dio turisticke ponude u Hrvatskoj. Prakticni Menadzment, V (1), 62-67.

Djordjevic, J., Pavlicevic, N., Boskovic, M., Baltic, T., Ivanovic, J., Glamoclija, N. \& Baltic, M. Z. (2016). Sensory evaluation of cold-smoked trout packaged in vacuum and modified atmosphere. Meat Technology, 57 (2), $141-149$

Espinosa, M. C., Díaz, P., Linares, M. B., Teruel, M. R. \& Garrido, M. D. (2015). Quality characteristics of sous vide ready to eat seabream processed by high pressure. LWT - Food Science and. Technology, 64, 657-662.

European Chilled Food Federation (ECFF). (2006). Recommendations for the production of prepackaged chilled foods. (http://www.ecff.net/images/ECFF Recommendations_2nd_ed_18_12_06.pdf).

García-Linares, M. C., Gonzalez-Fandos, E., García-Fernández, M. C. \& García-Arias, M. T. (2004). Microbiological and nutritional quality of sous vide or traditionally processed fish: influence of fat content. Journal of Food Quality, 27, 371-387.

Gonzalez-Fandos, E., Garcia-Linares, M. C., Villarino-Rodriguez, A., Garcia-Arias, M. T. \& Garcia-Fernandez, M. C. (2004). Evaluation of the microbiological safety and sensory quality of rainbow trout (Oncorhynchus mykiss) processed by the sous vide method. Food Microbiology, 21, 193-201.

Gould, G. W. (1999). Sous vide foods: conclusions of an ECFF botulinum working party. Food Control, 10, 47-51.

Guillén, S., Mir-Bel, J., Oria, R. \& Salvador, M. L. (2017). Influence of cooking conditions on organoleptic and health-related properties of artichokes, green beans, broccoli and carrots. Food Chemistry, 217, 209-216.

Henderikx, F., 2017. Labeling of food: A challenge for many. Veterinarski Glasnik, 71 (1), 16-23.

Iborra-Bernad, C., Philippon, D., García Segovia, P. \& Martínez Monzó, J. (2013). Optimizing the texture and color of sous vide and cook-vide green bean pods. $L W T$ - Food Science and Technology, 51 (2), 507-513.
Iborra-Bernad, C., Tárrega, A., García-Segovia, P. \& Martínez-Monzó, J. (2014a). Advantages of sous vide cooked red cabbage: Structural, nutritional and sensory aspects. LWT - Food Science and Technology, 56, 451-460.

Iborra-Bernad, C., Tárrega, A., García-Segovia, P. \& Martínez-Monzó, J. (2014b). Comparison of sous vide treatments and traditional cooking using instrumental and sensory analysis. Food Analytical Methods, 7, 400-408.

Iborra-Bernad, C., García, P. \& Martínez-Monzó, J. (2015). Physico-chemical and structural characteristics of vegetables coked under sous vide, cook-vide, and conventional boiling. Journal of Food Science, 8, 1725-1734.

Jacob, J. J. (2016). Fish consumption and omega-3-fatty acids in prevention of diet-related noncommunicable diseases. Journal of Social Health and Diabetes, 4 (2), 115-120.

Jay, J. M. (1992). Microbiological food safety. Critical Reviews in Food Science and Nutrition, 31, 177-190.

Kalenjuk, B., Tesanovic, D., Gagic, S., Erdeji, I. \& Banjac, M. (2015). Offer of authentic food as a condition for gastronomic tourism development. The European Journal of Applied Economics, 12 (2), 27-34.

Keller, T. (2008). Under pressure: cooking sous vide. Artisan, New York, USA

Kilibarda, N., Baltic, Z. M., Dimitrijevic, M., Karabasil, N. \&Teodorovic, V. (2009). The smoked fish - Producing and quality, 4. International Conference "Fishery" Faculty of Agriculture, Belgrade-Zemun, Proceedings, 296-306.

Kilibarda, N. (2010). Comparative study of selected quality parameters during storage of cold smoked trout packed in vacuum and modified atmosphere, $\mathrm{PhD}$ Thesis, Faculty of Veterinary Medicine, University of Belgrade, Serbia

Kosewski, G., Górnaa, I., Bolesławska, I., Kowalówka, M., Więckowska, B., Główka, A. K., Morawska, A., Jakubowski, K., Dobrzyńska, M., Miszczuk, P. \& Przysławski, J. (2018). Comparison of antioxidative properties of raw vegetables and thermally processed ones using the conventional and sous vide methods. Food Chemistry, 240, 1092-1096.

Köster, E. P. \& Mojet, J. (2015). From mood to food and from food to mood: A psychological perspective on the measurement of food-related emotions in consumer research. Food Research International, 76, 180-191.

Nyati, H. (2000). An evaluation of the effect of storage and processing temperatures on the microbiological status of sous vide extended shelf-life products. Food Control, 11, 471-476.

Odusanya, I. A. \& Atanda, A. A. (2018). Income-health nexus in sub-Saharan Africa: Evidence from heterogeneous panel models. The European Journal of Applied Economics, 15 (1), 94-109.

Oniang'o, R. (2016). "You are what you eat", indeed: Nutrition Matters. African Journal of Food, Agriculture, Nutrition and Development, 16 (2), Editorial.

Pavlicevic, N., Baltic, M. Z., Dimitrijevic, M., Karabasil, N., Djordjevic, V., Markovic, R. \& Grbic, S. (2014). Polyunsaturated fatty acids in the fish meat and their significance for human health. Meat Technology, 55 (1), 1-7.

Peck, M. W., Goodburn, K. E., Betts, R. P. \& Stringer, S. C. (2006). Clostridium botulinum in Vacuum Packed (VP) and Modified Atmosphere Packed (MAP) Chilled Foods. Final Project Report (b13006). Technical Report. Institute of Food Research. 
Peck, M. W., Goodburn, K. E., Betts, R. P. \& Stringer, S. C. (2008). Assessment of the potential for growth and neurotoxin formation by non-proteolytic Clostridium botulinum in short shelf-life commercial foods designed to be stored chilled. Trends in Food Science and Technology, 19 (4), 207-216.

Petersen, M. A. (1993). Influence of sous vide processing, steaming and boiling on vitamin retention and sensory quality in broccoli florets. Zeitschrift fur Lebensmittel Untersuchung und Forschung, 197 (4), 375-380.

Picouet, P. A., Cofan-Carbo, S., Vilaseca, H., Ballbè, L. C. \& Castells, P. (2011). Stability of sous vide cooked salmon loins processed by high pressure. Innovative Food Science and Emerging Technologies, 12, 26-31.

Renna, M., Gonnella, M., Giannino, D. \& Santamaria, P. (2014). Quality evaluation of cook-chilled chicory stems (Cichorium intybus L., Catalogna group) by conventional and sous vide cooking methods. Journal of the Science of Food and Agriculture, 94, 656-665.

Roascio-Albistur A. \& Gámbaro, A. (2018). Consumer perception of a non-traditional market on sous vide dishes. International Journal of Gastronomy and Food Science, 11, 20-24

Roldán, M., Ruiz, J., del Pulgar, J. S., Pérez-Palacios, T. \& Antequera, T. (2015). Volatile compound profile of sous vide cooked lamb loins at different temperature-time combinations. Meat Science, 100, 52-57.

Rondanelli, M., Daglia, M., Meneghini, S., Di Lorenzo, A., Peroni, G., Faliva, M. A. \& Perna, S. (2017). Nutritional advantages of sous vide cooking compared to boiling on cereals and legumes: Determination of ashes and metals content in ready-to-eat Products. Food Science and Nutrition, 5 (3), 827-833.

Sánchez del Pulgar, J., Gázquez, A. \& Ruiz-Carrascal, J. (2012). Physico-chemical, textural and structural characteristics of sous vide cooked pork cheeks as affected by vacuum, cooking temperature, and cooking time. Meat Science, 90, 828-835.

Schellekens, M., (1996). New research issues in sous vide cooking. Trends in Food Science and Technology 7, 256-262.

Steward, M. \& Onyeaka, H. (2015). Sous vide and/or low temperature cooking or processing. Food Standards Agency (https://www.food.gov.uk/sites/default/files/sousvide.pptx)

Stringer, S. C \& Metris, A. (2018). Predicting bacterial behavior in sous vide food, International Journal of Gastronomy and Food Science, article in press.

Trejo Araya, X. I., Smale, N., Zabaras, D., Winley, E., Forde, C., Stewart, C. M. \& Mawson, A. J. (2009). Sensory perception and quality attributes of high pressure processed carrots in comparison to raw, sous vide and cooked carrots. Innovative Food Science and Emerging Technologies, 10, 420-433.

Vaudagna, S. R., Pazos, A. A., Guidi, S. M., Sanchez, G., Carp, D. J. \& Gonzalez, C. B. (2008). Effect of salt addition on sous vide cooked whole beef muscles from Argentina. Meat Science, 79, 470-48. 